\title{
BIODEGRADATION OF AZO DYE (REACTIVE GREEN 19) BY Pseudomonas aeruginosa ISOLATED FROM TEXTILE EFFLUENT
}

\author{
BADRUL KHALID ARIFFIN and FAZILAH ARIFFIN* \\ Faculty of Science and Marine Environment, Universiti Malaysia Terengganu, \\ 21030 Kuala Nerus, Terengganu, Malaysia \\ *E-mail: fazilah@umt.edu.my
}

Accepted 24 November 2020, Published online 25 December 2020

\begin{abstract}
Azo dyes are widely used in the textile industry. The release of these undesirable dye effluents to the environment can be toxic and carcinogenic towards humans and other organisms. The removal of these dyestuff wastes using the biodegradation method is to consider eco-friendlier compared to physical and chemical methods. Thus, this study was conducted to identify and analyze the biodegradation activity of the azo dye by the potential bacteria isolated from textile dye effluent. For decolorization analysis, the isolated bacteria were inoculated into flasks containing mineral salt medium added with Reactive Green 19 dye $(50 \mathrm{mg} / \mathrm{L})$ and was incubated for 9 days at $37^{\circ} \mathrm{C}$. Spectrophotometry analysis was carried out at $635 \mathrm{~nm}$ to analyze the level of azo dye degradation. From the analysis, we found that the optimum $\mathrm{pH}$, temperature, and dye concentration for the decolorization were detected at $\mathrm{pH} 7,37^{\circ} \mathrm{C}$, and $50 \mathrm{mg} / \mathrm{L}$, respectively. The identified bacteria Pseudomonas aeruginosa showed $94 \%$ decolorization of Reactive Green 19 dye after 9 days of incubation. The result of decolorization activity by this bacterial strain can be used in the biological treatment of textile effluent.
\end{abstract}

Key words: Decolorization, reactive green 19 dye, Pseudomonas aeruginosa, pH, temperature, dye concentration

\section{INTRODUCTION}

Every year, over 65,000 metric tons of synthetic dyes are manufactured worldwide (Oh et al., 2011). The dye is utilized in the textile, paper, beauty care products, sustenance, and pharmaceutical businesses because of its low cost of production, speed, and color varieties compared to natural dyes. The reactive group of azo dyes is mainly used in textile dye industries due to its high fixing property and excellent sturdiness to the applied fabric (Ayaz et al., 2018). 70\% of every single material dyestuff consists of azo dyes (Sinha \& Osborne, 2016). Approximately 4,500,000 tons of dyes are lost as effluents every year (Rawat, Mishra \& Sharma, 2016). The textile industry wastewater has shown a moderate increase in recent times, making it one of the well-known sources of extreme contamination around the world and the wastewater is dangerous

\footnotetext{
* To whom correspondence should be addressed.
}

to living organisms due to their possible toxicity and carcinogenicity (El-Kassas \& Mohamed, 2014).

The decrease in water transparency and oxygen solubility occurs in the water resources due to the discharge of azo dyes from the textile processing industry (Corso \& Maganha De Almeida, 2009). In aquatic systems, the dyes undergo several reactions and metabolisms to alter their chemical structures. This results in the production of new xenobiotic metabolites that might be less or more harmful to the environment rather than the parental compounds. Hence, the treatment of textile wastewater is essential to ensure its safety before it can be released into the aquatic systems (Holkar et al., 2016). Dye effluent can be removed from the wastewater using physical and chemical methods including oxidation, adsorption, coagulationflocculation, and electrochemical methods. However, the applications of both the physical and chemical methods have numerous disadvantages, for example, high-vitality costs, high-sludge formation, and production of by-products that may cause 
secondary pollution issues (Wang et al., 2009). Biodegradation processes are very promising for the decolorization of synthetic azo dyes. This is due to its eco-friendly process, economically, and it produces fewer toxic compounds (Wang et al., 2009). The mixed microbial consortia including bacteria, fungi, yeasts, and algae have been screened out and utilized for the dye decolorization in an eco-friendly manner (Das \& Mishra, 2017; Man \& Hameed, 2019).

However, choosing the best azo dye decolorizing bacteria is critical. Therefore, the reason for isolating bacteria from contaminated sites especially at textile wastewater sites because it is an effective way to isolate bacteria that have the potential ability to decolorize synthetic commercial dyes used for textile dye. This study can provide new sources and more information about the microbial degradation activity by bacteria isolated from the textile effluent near a small textile factory that operates the dyeing method located nearby Kampung Pak Tuyu, Kuala Nerus, Terengganu. This study can also help our community to have a better understanding of the microbial degradation towards the textile effluent since the pollution of water resources caused by azo dye is a major concern due to its possible toxicity, carcinogenicity, and the fact that it can be harmful to aquatic organisms and human beings.

\section{MATERIALS AND METHODS}

\section{Chemicals and dyestuff}

The textile dye, RG-19 used in this study was obtained from Sigma- Aldrich. The textile effluent sample used as the source of dye degrading bacteria was collected from a small textile factory which is located nearby Kampung Pak Tuyu, Kuala Nerus, Terengganu. The untreated textile effluent sample was collected in three different sites at a dye waste container. The samples were kept in a sterile $500 \mathrm{~mL}$ blue cap bottle and stored at $4^{\circ} \mathrm{C}$. A stock solution of RG-19 dye was prepared $(10,000 \mathrm{mg} / \mathrm{L})$, and the desired concentrations of the dye were obtained by further subsequent dilutions.

\section{The medium used for culture maintenance and decolorization study}

Nutrient broth culture was used for isolation of potential dye degrading bacteria. All the decolorization and optimization experiments were done in a mineral salt medium (MSM). The MSM used had the following composition per litre: $1.8 \mathrm{~g} / \mathrm{L} \mathrm{K}_{2} \mathrm{HPO}_{4}, 4.0 \mathrm{~g} / \mathrm{L} \mathrm{NH} \mathrm{NH}_{4} \mathrm{Cl}, 0.2 \mathrm{~g} / \mathrm{L}$ $\mathrm{MgSO}_{4} .7 \mathrm{H}_{2} \mathrm{O}, 0.1 \mathrm{~g} / \mathrm{L} \mathrm{NaCl}, 0.1 \mathrm{~g} / \mathrm{L} \mathrm{FeSO}_{4} \cdot 7 \mathrm{H}_{2} \mathrm{O}$, $0.02 \mathrm{~g} / \mathrm{L} \mathrm{CaCl}_{2}, 5.0 \mathrm{~g} / \mathrm{L}$ dextrose at $\mathrm{pH}$ 7. The bacterial strains were maintained on the nutrient agar slant at $4^{\circ} \mathrm{C}$ before use. The organisms from the stock cultures were used for further decolorization study.

Isolation and screening of dye degrading bacteria The potential dye degrading bacterial strains were isolated from the textile effluent samples using the enrichment culture technique. After $48 \mathrm{hr}$ of enrichment, $0.1 \mathrm{~mL}$ of the enrichment sample in the nutrient broth was spread onto nutrient agar containing $0.1 \mathrm{~g} / \mathrm{L}$ of RG-19 dye. The assay plate was then incubated for $24 \mathrm{hr}$ at $37^{\circ} \mathrm{C}$. After the incubation, the growing bacterial colonies which produced a clear zone against the color of the dye was isolated and grown in another nutrient agar consist of $0.1 \mathrm{~g} / \mathrm{L}$ of reactive green $19 \mathrm{~A}$ dye to gain the pure culture of the desired bacteria. The plates were incubated for $24 \mathrm{hr}$ at $37^{\circ} \mathrm{C}$. Pure cultures of bacteria were then stored on the nutrient agar slant at $4{ }^{\circ} \mathrm{C}$.

\section{Identification of isolated bacteria}

The desired bacteria underwent identification through morphological characteristics and biochemical tests. The pure culture of the selected isolated bacteria was examined in terms of its morphological properties, such as shape, form, color, margin, elevation, and the surface of the colonies on the nutrient agar plate. Gram staining and biochemical tests (Indole test, oxidase test, urease test, citrate test, nitrate test, and catalase test) were performed as described in Bergey's Manual of Determinative Bacteriology. The preliminary identification of the isolated bacteria was carried out using the BBL Crystal Identification system. The bacterial isolates at a molecular level were further characterized through $16 \mathrm{~S}$ rRNA sequencing analysis.

\section{Optimization of decolorization conditions}

The ability of isolated bacteria to decolorize the RG-19 dye in various concentrations was studied. The desired bacteria were grown and incubated with $25 \mathrm{~mL}$ of MSM and RG- 19 dye. The mixtures were tested on different parameters (temperature, $\mathrm{pH}$, and concentration of dye). The mixtures were stimulated using various conditions (temperatures are $28^{\circ} \mathrm{C}$, $37^{\circ} \mathrm{C}$, and $50^{\circ} \mathrm{C}$; the $\mathrm{pH}$ are $3,5,7$, and 10 ; the concentration of RG-19 dye is $50 \mathrm{mg} / \mathrm{L}, 100 \mathrm{mg} / \mathrm{L}$, $150 \mathrm{mg} / \mathrm{L}$, and $250 \mathrm{mg} / \mathrm{L}$ ). For each parameter, the mixtures were incubated for $72 \mathrm{hr}$ and then were analyzed using a UV-Vis spectrophotometer with a wavelength of $635 \mathrm{~nm}$.

\section{Dye degradation analysis}

The decolorization process of isolated bacteria was further analyzed by observing the incubation period for 9 days. The dye degradation analysis was 
performed using three types of setup with different compositions were prepared in different flasks (Sample A, Control 1, and Control 2). Sample A consists of desired bacteria, RG-19 dye, and MSM. Control 1 does consist of selected bacteria and MSM only, while Control 2's consists of RG-19 dye and MSM. All three setups were exposed to the different parameters $(\mathrm{pH}$, temperature, and concentration of RG-19 dye). The three solutions were then incubated for 9 days. Every three days, Sample A and Control 1 were centrifuged at $8000 \mathrm{rpm}$ for $10 \mathrm{~min}$, and the supernatant was collected and analyzed using a spectrophotometer at the wavelength of $635 \mathrm{~nm}$. The percentage of decolorization was calculated using the formula shown:

$$
\text { Decolorization }(\%)=\frac{\begin{array}{c}
\text { Initial absorbance }- \\
\text { Final absorbance }
\end{array}}{\text { Initial absorbance }} \times 100
$$

\section{RESULTS}

\section{Isolation of dye-decolorizing bacteria}

A single bacterial colony with the ability to completely decolorize RG-19 dye in the nutrient broth culture was then used as a dye decolorizing agent for subsequent studies.

\section{Identification of isolated bacteria}

The desired bacteria were successfully identified as Gram-negative and rod-shaped bacteria (Figure 2a). The colony morphology produces large, opaque, and flat colonies with irregular margins that form yellow-greenish color. It releases a 'sweet' grape-like odor (Figure 2b). The biochemical tests are depicted in Table 1. The isolated bacteria showed a positive result in the oxidase, citrate, nitrate, and catalase test. Figure 3 shows the phylogenetic relationships derived from 16S rRNA gene sequence analysis shows the desired bacteria fall closest relative to Pseudomonas aeruginosa.

The results in Table 1 show that some biochemical tests conducted on the isolated bacteria were found to be both negative and positive. The negative results were for the indole production test and urease biochemical activities. Meanwhile, positive results were obtained for oxidase, citrate, nitrate, and catalase biochemical activities.

\section{Optimization of dye degradation condition}

The isolated bacteria are found to be more efficient in decolorizing RG-19 dye at a lower concentration $(50 \mathrm{mg} / \mathrm{L})$. At a lower concentration, $66.2 \%$ of decolorization was noticed, which was further reduced to $11.2 \%$ of decolorization at a higher concentration $(250 \mathrm{mg} / \mathrm{L})$ after $72 \mathrm{hr}$ of incubation at $37^{\circ} \mathrm{C}$ (Figure 4). The decolorization capacity of the isolated bacteria was analyzed at a wide range of $\mathrm{pH}$ levels $(3,5,7$, and 10) and the results are shown in Figure 5. The figure shows that the maximum decolorization of RG-19 dye (50 mg/L) was $68.2 \%$, which was found at $\mathrm{pH} 7$ with $37^{\circ} \mathrm{C}$ incubation temperature for $72 \mathrm{hr}$. Treatment in $\mathrm{pH} 3$ and $\mathrm{pH} 10$ resulted in the lowest decolorization of dye; $2.1 \%$ and $1.1 \%$ since it was considered as high acidic and alkaline conditions, respectively. At $\mathrm{pH} 5$, the bacteria showed a reduction in decolorization of RG-19 dye at 30.8\%. Thus, the optimum $\mathrm{pH}$ was found to be 7 for the maximum removal of dye.

Incubation temperature was found to have a profound effect on the efficacy of the bacteria to decolorize the RG-19 dye. Figure 6 shows the results of decolorization of the RG-19 dye after incubation at three different temperatures $\left(28^{\circ} \mathrm{C}\right.$, $37^{\circ} \mathrm{C}$, and $50^{\circ} \mathrm{C}$ ) at the dye concentration of 50 $\mathrm{mg} / \mathrm{L}$ and $\mathrm{pH} 7$. It is clear from the figure that the optimum temperature was $37^{\circ} \mathrm{C}$ for maximum decolorization of the RG-19 dye (67.3\%) by isolated bacteria. The incubation temperature at $28^{\circ} \mathrm{C}$ was the second highest decolorization of dye (55.2\%), and there was a reduction at $50^{\circ} \mathrm{C}(37.3 \%)$.

\section{Dye degradation analysis}

Figure 7 shows the decolorization of RG-19 dye after nine days of incubation in static conditions. Optimum parameters were selected in culturing the bacteria to get maximum decolorization with $\mathrm{pH} 7$, the temperature at $37^{\circ} \mathrm{C}$, and $50 \mathrm{mg} / \mathrm{L}$ dye concentration. The results showed the exponential decolorization from $66.3 \%$ on day three to $94 \%$ of

Table 1. Biochemical tests for the isolated bacteria

\begin{tabular}{ll}
\hline Biochemical tests & Results \\
\hline Indole & Negative with no red color ring formation \\
Oxidase & Positive with the dark blue formation \\
Urease & Negative with no dark pink formation \\
Citrate & Positive with the blue color formation \\
Nitrate & Positive with the cherry color formation \\
Catalase & Positive with bubbles formation \\
\hline
\end{tabular}




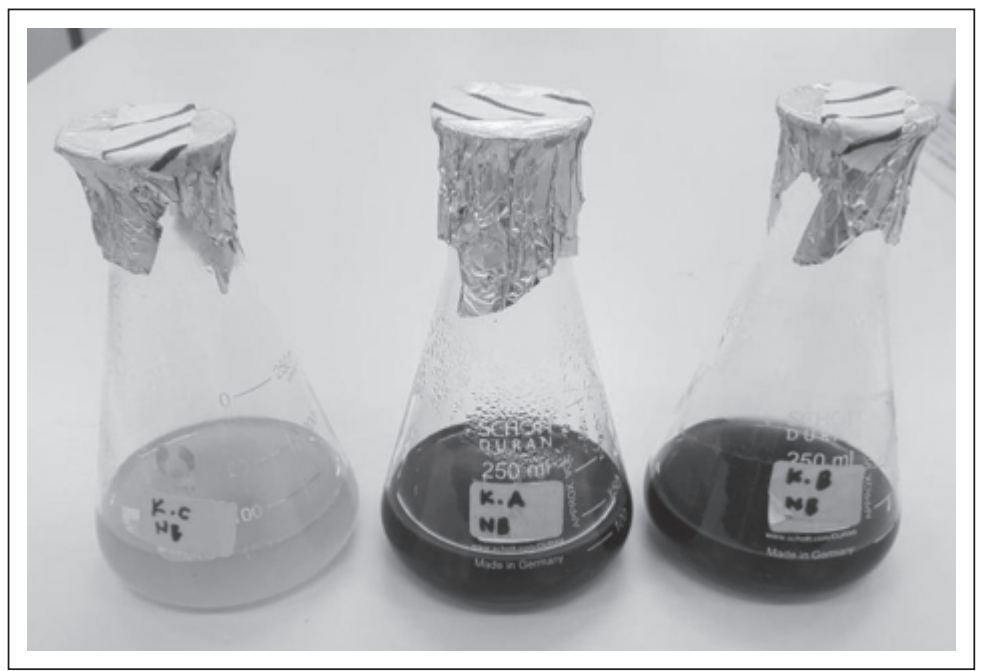

Fig. 1. Decolorization of RG-19 dye by Isolate K.C (from green to yellow) after $24 \mathrm{hr}$ of incubation.

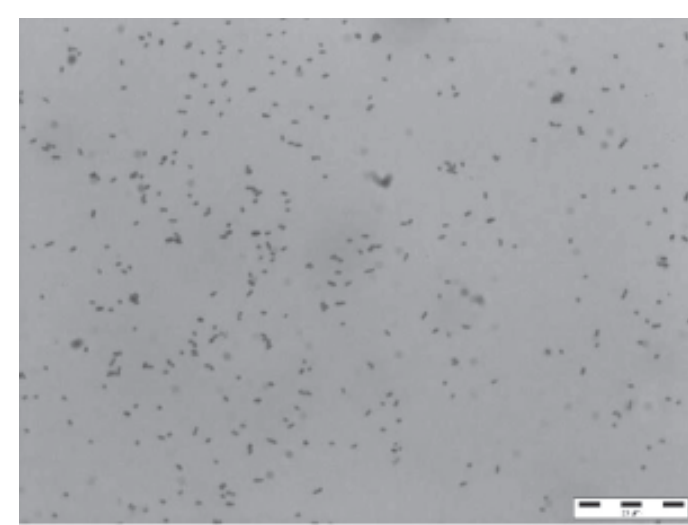

(a)

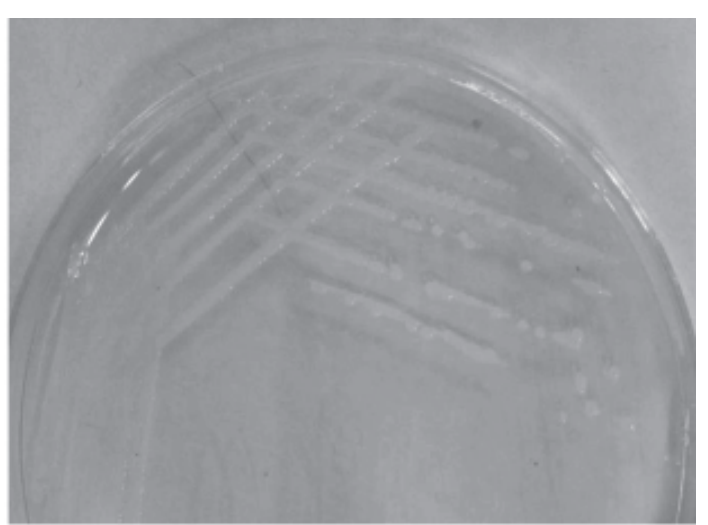

(b)

Fig. 2. Morphology characteristics of isolated bacteria (a) Microscopic observation under $100 \times$ magnification (b) Macroscopic observation on nutrient agar after $24 \mathrm{hr}$ of incubation.

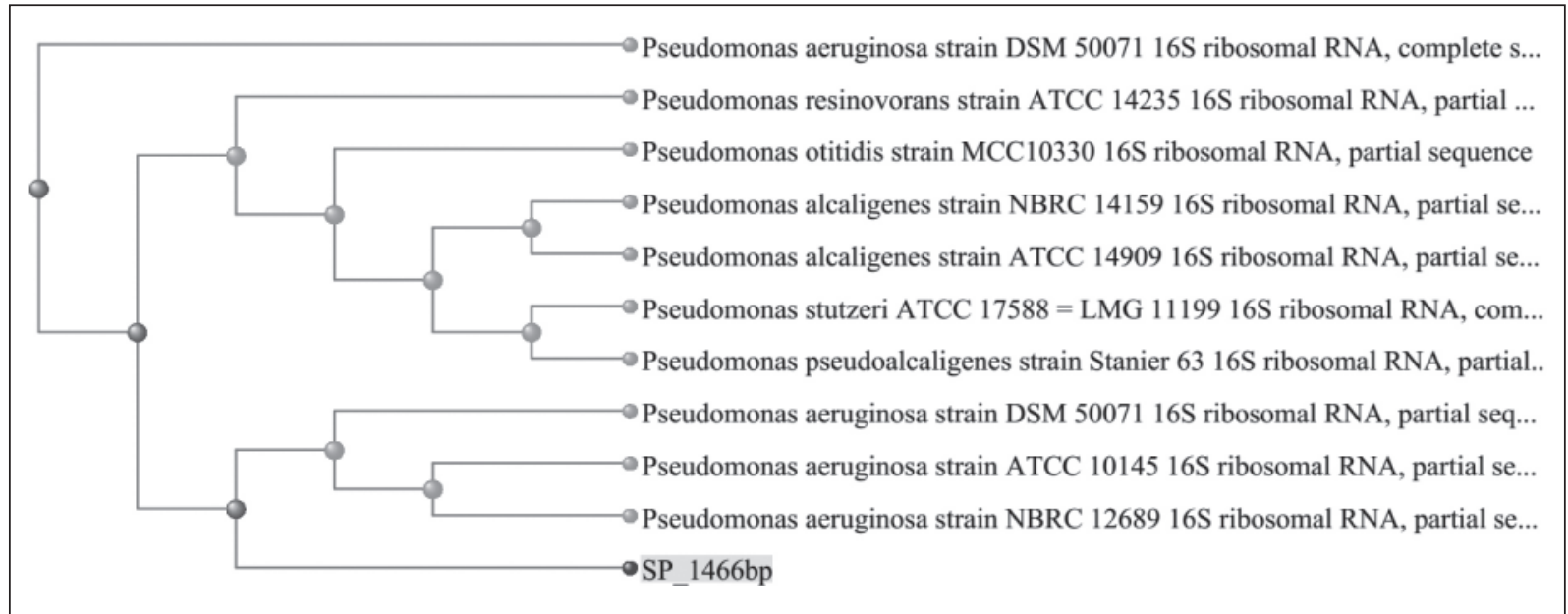

Fig. 3. Phylogram showed a genetic relationship between the isolated bacteria and other related reference microorganisms based on the 16S rRNA gene sequence analysis. 


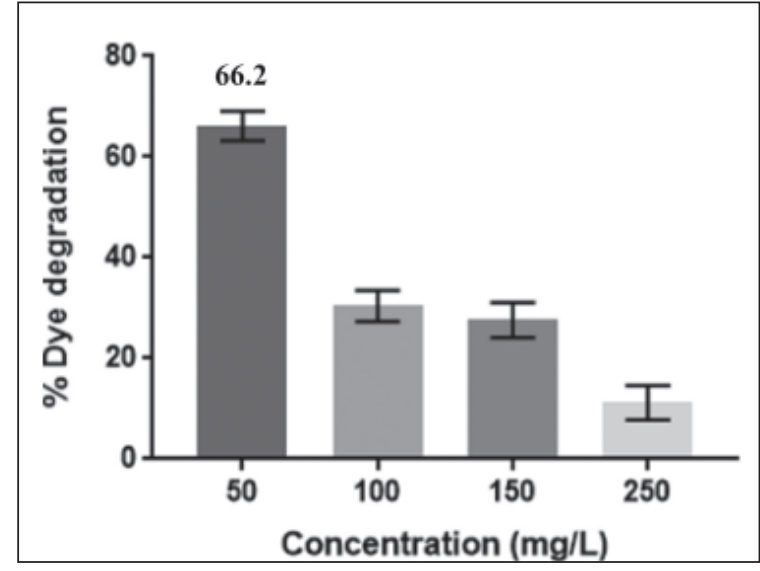

Fig. 4. Comparative decolorization efficiency of Pseudomonas aeruginosa at different dye concentrations after $72 \mathrm{hr}$ incubation in MSM supplemented with RG-19 dye.

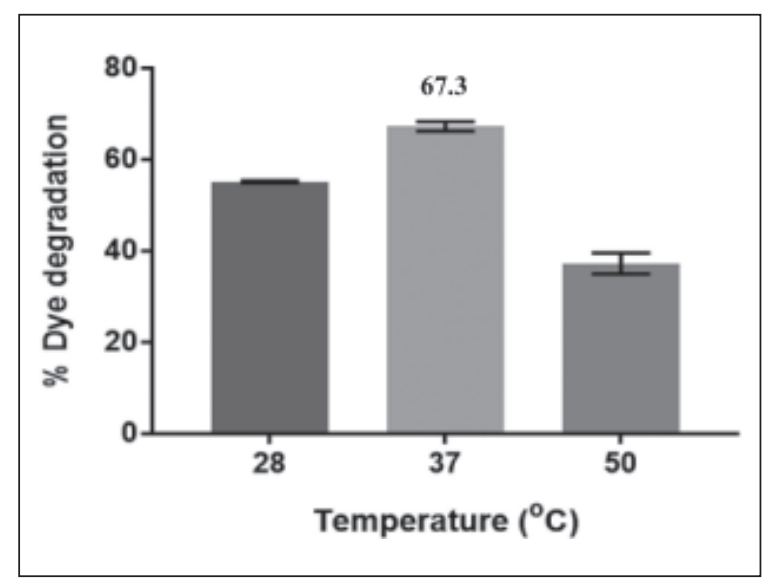

Fig. 6. Comparative decolorization efficiency of Pseudomonas aeruginosa at different temperatures after $72 \mathrm{hr}$ incubation in MSM supplemented with RG-19 dye.

dye decolorized after nine days of incubation, where the RG-19 dye was almost completely degraded.

\section{DISCUSSION}

\section{Isolation and screening of decolorizing bacteria}

Textile dye effluent sample was used to isolate dye decolorizing bacteria as it is a habitat for the living microbes by utilizing the food source contained in the effluent. Due to high contaminants such as textile dye effluent, some microbial communities developed the ability to degrade them due to the exposure of recalcitrant contaminants over a long period (Prabha et al., 2017). A total of 3 bacterial strains were isolated and purified by subculturing on nutrient agar plates. All the isolated cultures were further screened for dye decolorization in a liquid medium as shown in Figure 1. The result

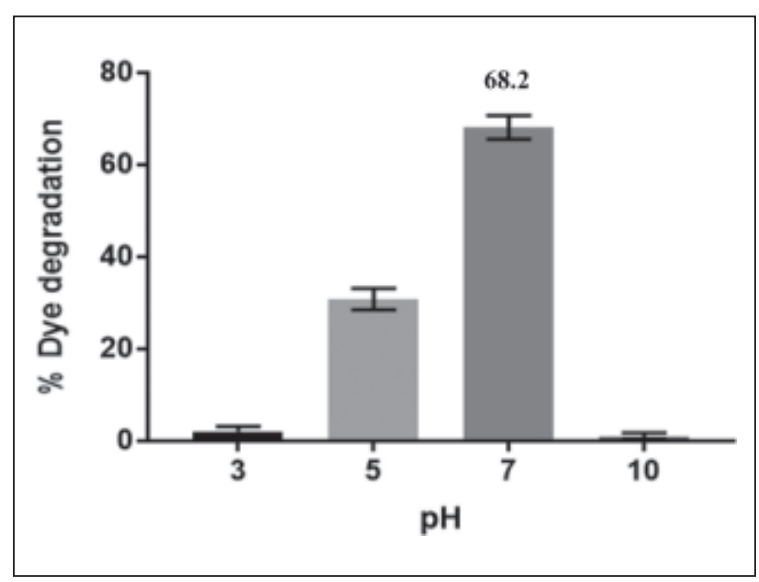

Fig. 5. Comparative decolorization efficiency of Pseudomonas aeruginosa at different $\mathrm{pH}$ after $72 \mathrm{hr}$ incubation in MSM supplemented with RG-19 dye.

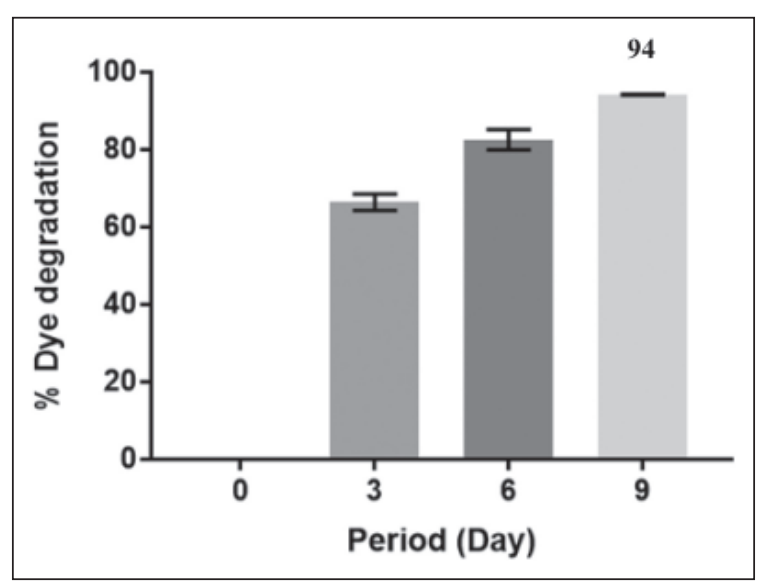

Fig. 7. Decolorization of RG-19 dye after 9 days of incubation in $\mathrm{MSM}$ (at $\mathrm{pH} 7,37^{\circ} \mathrm{C}$, and $50 \mathrm{mg} / \mathrm{L}$ concentration of dye).

obtained shows that Isolate K.C decolorized dye which changed the color of the medium from green to yellow. The mechanism involves in this process occurs because of the reductive cleavage of azo bonds $(-\mathrm{N}=\mathrm{N}-)$ with the help of azoreductase (Gao et al., 2018). It resulted in dye decolorization and the formation of colorless solutions. This isolated bacterium was then used as a dye decolorizing agent for subsequent studies. The effectiveness of the isolated bacteria from textile wastewater implies that these can be effectively used for the removal of RG-19 dye from contaminated textile wastewater.

\section{Identification of decolorizing bacteria}

The bacterial isolate was mainly identified based on their microscopic and cultural characteristics. Based on that, the isolated bacterial was found to be Gram-negative. The cell wall of the bacterium determines whether it is Gram-positive or 
negative (Burke \& Barnes, 1929). Since Gramnegative bacteria have a thin peptidoglycan layer (1-2 layers) and have an additional lipopolysaccharide layer in its wall, it cannot retain the crystal violet color when it is decolorized by alcohol. Thus, safranin which is a counterstain was added, which gave a red color to the Gram-negative bacteria (Beveridge, 2001). Figure 2a shows the microscopic image of the desired bacteria from the textile effluent sample that was stained.

For the biochemical test, it is revealed that this isolated bacterium can produce the enzyme citrate permease (citrate as a carbon and energy source), nitrate reductase enzyme, and catalase enzyme (Table 1) similar to Mahon et al. (2018) reported data. The desired bacteria successfully identified as Pseudomonas aeruginosa bacteria through the BBL Crystal.

Identification System and the molecular approach using 16S rRNA gene analysis. Similar findings have been reported by Mahbub et al. (2015) and Kamal (2018), identified Gram-negative bacterial strain which is Pseudomonas aeruginosa that capable of degrading dyes such as Novacron Super Black-G, Novacron Yellow S-3R, Novacron Dark Blue C-B, and Novacron Navy S-GI.

\section{Effect of dye concentrations}

It was observed that Pseudomonas aeruginosa can degrade $50 \mathrm{mg} / \mathrm{L}$ RG-19 dye within $72 \mathrm{hr}$. However, in higher concentrations at $100 \mathrm{mg} / \mathrm{L}$ to $250 \mathrm{mg} / \mathrm{L}$, the dye degradation rate was remarkably reduced (Figure 4). This may be due to the decreasing of nucleic acids content ratio which is RNA/DNA. It may result in lowering the protein synthesis that inhibits cell division (Roy et al., 2018). Previous studies had also explained this reduction, Bhatt et al. (2005) and Prasad (2014) stated that dye decolorization reduced with the increase in the dye's concentration which can be attributed to the toxic activity of the dye on the bacterial enzyme system. The effect of dye concentration plays an important role in the selection of microorganisms in the process of bioremediation of textile wastewater, for instance, high dye concentrations may reduce the degradation efficiency due to the toxic effect of the dyes (Khehra et al., 2006).

\section{Effect of pH}

In the case of RG-19 dye decolorization by Pseudomonas aeruginosa, it was observed that the removal efficiency was reached $(68.2 \%)$ at $\mathrm{pH} 7$. Thereafter, whenever the $\mathrm{pH}$ values increase or decrease, the decolorization process appeared to be decreased. Similar results have been reported by many researchers where the maximum color removal was usually at neutral or slightly alkaline $\mathrm{pH}$ value and the decline in the rate of color removal tends to occur at strong acid and strong alkaline $\mathrm{pH}$ values (Evans \& Furlong, 2003; Kamal, 2018). These observations indicated that this bacterial could be treated efficiently at neutral to weakly acidic or weakly alkaline dyeing waste. In another research done by Wang et al. (2009), Citrobacter sp. CK3 had achieved the best decolorization of reactive red $180(96 \%)$ at $\mathrm{pH} 6.0-7.0$.

\section{Effect of incubation temperature}

Figure 6 shows the optimum temperature for decolorization was $37^{\circ} \mathrm{C}$ with $67.3 \%$ by Pseudomonas aeruginosa. Factor such as incubation temperature is important to produce the maximum rate of color removal as it tends to correspond with the optimum cell growth temperature which is in the range between $35-45^{\circ} \mathrm{C}$. The higher temperature causes thermal inactivation of proteins in the bacteria cell structures such as the membrane (Shah, 2013). Similar findings by Saratale et al. (2009) had shown that maximum decolorization occurred at $37^{\circ} \mathrm{C}$. Higher temperature conditions can impact the enzymatic system of the bacteria. Shah et al. (2013), reported that the decline in color removal activity at higher temperatures could be attributed to the loss of cell viability or the denaturation of the azoreductase enzyme. A similar effect of temperature $\left(37^{\circ} \mathrm{C}\right)$ was observed in Congo Red dye degradation showed $92.56 \%, 91.37 \%, 89.29 \%$, and $88.69 \%$ by B. cereus MAM-B22, Ochrobacterum sp. MAM-C9, A. xylosoxidans MAM-29, and B. cereus MAM-B11 (Abo-State et al., 2017).

\section{Dye degradation analysis}

The results showed the decolorization rate was up to $94 \%$ after nine days of incubation (Figure 7). The present decolorization result was in agreement with the findings reported by Rahman et al. (2005) that decolorization of Red 81 dye was obtained in treated culture by a similar bacterium which is Pseudomonas aeruginosa strain ZJHG29 (DR4) within $24 \mathrm{hr}$. However, the decolorization rate was found to be slower compared to other studies. A study by Saratale et al. (2009) showed 100\% decolorization of Reactive Green 19A dye using Micrococcus glutamicus at $42 \mathrm{hr}$ incubation. On the other hand, a study by Das and Mishra (2017) showed 97\% decolorization of the Reactive Green 19 dye using bacterial consortium was achieved within $24 \mathrm{hr}$. The differences in the decolorization rate can be affected by several factors, including $\mathrm{pH}$, concentration, temperature, carbon and nitrogen sources, and types of microorganisms.

Pseudomonas aeruginosa is unable to grow in the absence of glucose and thus affects the decolorization activity (Selvakumar et al., 2010). Many studies supported this factor where very few 
microorganisms are capable of using dye as their sole carbon source because of the complex structure of these compounds. Supplementation of suitable carbon and nitrogen sources are needed to assist an efficient decolorization activity. Bhatt et al. (2005), Prasad (2014), and Junior et al. (2015) have studied the same microorganism; Pseudomonas aeruginosa, and they used glucose and yeast extract as the sole source of carbon and nitrogen for the test organism.

\section{CONCLUSION}

In this study, Pseudomonas aeruginosa from textile effluent was successfully identified as a potential decolorizing bacterium for Reactive Green 19 dye. It can carry out the decolorization within 9 days. Therefore, we believe that Pseudomonas aeruginosa has the potential to treat textile effluent before flowing the effluent into the water bodies. Although decolorization with pure cultures has been reported as an effective tool by various researchers, the use of bacterial consortium may provide more realistic and efficient solutions to actual industrial effluent rather than pure culture. Therefore, further studies need to be carrying out to maximize the biodegradation process in the field, especially in textile wastewater.

\section{ACKNOWLEDGEMENT}

We would like to thank those directly or indirectly involved in completing this article writing process.

\section{REFERENCES}

Abo-State, M.A.M., Saleh, Y.E. \& Hazaa, H.A. 2017. Decolorization of Congo Red dye by bacterial isolates. Journal of Ecology of Health and Environment, 5(2): 41-48.

Ayaz, M., Ali, F., Saeed, A., Khurshid, A., Shabir, G., Ahmad, T. \& Khan, H.A. 2018. Synthesis of symmetric bridged bis-pyrazolone based metal complex acid dyes and their applications on leather. Journal of Fluorescence, 28(5): 11811193.

Beveridge, T.J. 2001. Use of the Gram stain in microbiology. Biotechnic \& Histochemistry, 76(3): 111-118.

Bhatt, N., Patel, K.C., Keharia, H. \& Madamwar, D. 2005. Decolorization of diazo- dye reactive blue 172 by Pseudomonas aeruginosa NBAR12. Journal of Basic Microbiology, 45(6): 407-418.

Burke, V. \& Barnes, M.W. 1929. The cell wall and the Gram reaction. Journal of Bacteriology, 18(2): 69.
Corso, C.R. \& Maganha De Almeida, A.C. 2009. Bioremediation of dyes in textile effluents by Aspergillus oryzae. Microbial Ecology, 57(2): 384-390.

Das, A. \& Mishra, S. 2017. Removal of textile dye reactive green-19 using bacterial consortium: Process optimization using response surface methodology and kinetics study. Journal of Environmental Chemical Engineering, 5(1): 612-627.

El-Kassas, H.Y. \& Mohamed, L.A. 2014. Bioremediation of the textile waste effluent by Chlorella vulgaris. Egyptian Journal of Aquatic Research, 40(3): 301-308.

Evans, G.M. \& Furlong, J.C. 2003. Environmental biotechnology: Theory and application. Journal of the Air and Waste Management Association, 53(11): 1418-1419.

Gao, Y., Yang, B. \& Wang, Q. 2018. Biodegradation and decolorization of dye wastewater: A review. IOP Conference Series: Earth and Environmental Science, 178(2018): 012013.

Holkar, C.R., Jadhav, A.J., Pinjari, D.V., Mahamuni, N.M. \& Pandit, A.B. 2016. A critical review on textile wastewater treatments: possible approaches. Journal of Environmental Management, 182: 351-366.

Junior, J.C.V., Cavalcanti, D.L., Alves da Silva, C.A., Andrade, R.F. \& Campos-Takaki, G.M. 2015. Decolorization of Black B azo dye by Pseudomonas aeruginosa. International Journal of Current Microbiology and Applied Science, 7: $720-728$.

Kamal, M. 2018. Effect of Physical Parameters on the Decolorization of Multiple Synthetic Textile Dyes by Bacteria Recovered from Dye Contaminated Soil and Water (Ph.D). Brac University.

Khehra, M.S., Saini, H.S., Sharma, D.K., Chadha, B.S. \& Chimni, S.S. 2006. Biodegradation of azo dye CI Acid Red 88 by an anoxic-aerobic sequential bioreactor. Dyes and Pigments, 70(1): 1-7.

Mahbub, K.R., Morium, B., Ahmed, M.M., Akond, M.A. \& Andrews, S. 2015. Decolorization of Novacron blue and Novacron super black azo dyes by Bacillus sp. isolated from textile effluents in Bangladesh. Journal of Scientific Research, 7(1-2): 45-53.

Mahon, C.R., Lehman, D.C. \& Manuselis, G. 2018. Textbook of Diagnostic Microbiology. Elsevier Health Sciences.

Mani, A. \& Hameed, S.A.S. 2019. Improved bacterial-fungal consortium as an alternative approach for enhanced decolourisation and degradation of azo dyes: A review. Nature Environment and Pollution Technology, 18(1): 49-64. 
Oh, Y.K., Seol, E.H., Park, S. \& Park, S. 2011. Decolorization of synthetic dyes by Citrobacter amalonaticus Y19. Journal of the Taiwan Institute of Chemical Engineers, 42(3): 492497.

O’Neill, C., Lopez, A., Esteves, S., Hawkes, F.R., Hawkes, D.L. \& Wilcox, S. 2000. Azo-dye degradation in an anaerobic-aerobic treatment system operating on simulated textile effluent. Applied Microbiology and Biotechnology, 53(2): 249-254.

Pandey, A., Singh, P. \& Iyengar, L. 2007. Bacterial decolorization and degradation of azo dyes. International Biodeterioration and Biodegradation, 59(2): 73-84.

Prabha, S., Gogoi, A., Mazumder, P., Ramanathan, A.L. \& Kumar, M. 2017. Assessment of the impact of textile effluents on microbial diversity in Tirupur district, Tamil Nadu. Applied Water Science, 7(5): 2267-2277.

Prasad, M. 2014. Studies on the degradation of textile dye by Pseudomonas aeruginosa. Research Journal of Recent Sciences, 3: 59-62.

Rahman, S.M.A., Saha, A.K., Ruhi, R.A., Haque, M.F. \& Mohanta, M.K. 2019. Decolorization of textile azo dye direct red 81 by bacteria from textile industry effluent. International Journal of Current Microbiology and Applied Sciences, 8(4): 1742-1754.

Rawat, D., Mishra, V. \& Sharma, R.S. 2016. Detoxification of azo dyes in the context of environmental processes. Chemosphere, 155: 591-605.
Roy, D.C., Biswas, S.K., Saha, A.K., Sikdar, B., Rahman, M., Roy, A.K. \& Tang, S.S. 2018. Biodegradation of Crystal Violet dye by bacteria isolated from textile industry effluents. Peer Journal, 6: e5015.

Saratale, R.G., Saratale, G.D., Chang, J.S. \& Govindwar, S.P. 2009. Ecofriendly degradation of sulfonated diazo dye C.I. Reactive Green 19A using Micrococcus glutamicus NCIM-2168. Bioresource Technology, 100(17): 3897-3905.

Selvakumar, K.V., Basha, C.A., Prabhu, H.J., Kalaichelvi, P. \& Nelliyan, S. 2010. The potential of free cells of Pseudomonas aeruginosa on textile dye degradation. Bioresource Technology, 101(8): 2678-2684.

Shah, M.P., Kavita, A.P., Sunu, S.N., Darji, A. \& Shaktisinh, M. 2013. Microbial degradation of Reactive red by Pseudomonas sp. MPS-2. Journal of Bioremediation and Biodegradation, 04(06): 6-12.

Shah, K. 2014. Biodegradation of azo dye compounds. International Research Journal of Biochemistry and Biotechnology, 1(2): 5-13.

Sinha, A. \& Osborne, W.J. 2016. Biodegradation of reactive green dye (RGD) by indigenous fungal strain VITAF-1. International Biodeterioration and Biodegradation, 114: 176-183.

Wang, H., Su, J.Q., Zheng, X.W., Tian, Y., Xiong, X.J. \& Zheng, T.L. 2009. Bacterial decolorization and degradation of the reactive dye Reactive Red 180 by Citrobacter sp. CK3. International Biodeterioration and Biodegradation, 63(4): 395-399. 